\title{
Is Service-Learning the Kind Face of the Neo-Liberal University?
}

\author{
Mary-Beth Raddon \\ Brock University \\ Barbara Harrison \\ University of Guelph
}

\begin{abstract}
The emergence of service-learning pedagogies in Canada has received a variety of critical responses. Some regard service-learning as a public relations effort of universities and colleges; others see it as a countermovement to academic corporatization; still others consider it part of a wider cultural project to produce self-responsible and socially responsible, enterprising citizens. In this article, we argue that each type of response rests on a different critique of the neo-liberal context of post-secondary education; these critiques, in turn, stem from different conceptions of neo-liberalism: as policy, ideology, or governance (Larner, 2000). Rather than attempt to resolve contradictions among these conceptualizations, we address them as a framework for understanding divergent responses to service-learning. We illustrate the framework with the example of a high-enrolment undergraduate course, and we call for future research and educative engagement with the politics of post-secondary servicelearning that is informed by a multi-faceted analysis of neo-liberalism.
\end{abstract}

\section{Résumé}

L'émergence au Canada de la pédagogie d'apprentissage par le service communautaire a suscité une grande variété de réactions. Certains y voient une opération de relations publiques de la part des universités et des collèges, d'autres un mouvement à l'encontre du corporatisme académique, d'autres encore un volet d'un vaste projet culturel ayant pour but de former des citoyens entreprenants, et responsables envers eux-mêmes et la société. Dans cet article, nous avançons que chacune de ces réactions repose sur une critique particulière du contexte néolibéral de la formation postsecondaire, 
découlant elle-même de conceptions diverses du néolibéralisme : comme politique, comme idéologie ou comme gouvernance (Larner, 2000). Plutôt que de tenter de résoudre les contradictions qui opposent ces concepts, nous en faisons le cadre qui permet de mieux comprendre les réactions divergentes face à l'apprentissage par le service communautaire. Nous illustrons ce cadre en donnant l'exemple d'un cours populaire du premier cycle, puis soulignons le besoin d'entreprendre des recherches et d'étayer, par une analyse du néolibéralisme à multiples facettes, la politique de l'apprentissage postsecondaire par le service communautaire.

In the context of neo-liberal transformations of post-secondary education, Canadian universities and colleges have been placing new emphasis on fostering relationships between campuses and communities (Jackson, 2014; Lightstone, 2014). A common approach to academy-community engagement has been service-learning, a method of teaching involving out-of-classroom activities that are designed to enrich students' academic learning while contributing something of value to community partners. While there are various definitions of service-learning in literature emanating from the United States, on which Canadian approaches are said to build (Smith, 2010), it is generally held that service-learning involves an "integration of academic material, relevant community-based service activities, and critical reflection in a reciprocal partnership that engages students, faculty/staff, and community members to achieve academic, civic, and personal learning objectives as well as to advance public purposes" (Bringle \& Clayton, 2012, p. 105).

Much of the research literature on service-learning in post-secondary education evaluates its potential either to reform pedagogy or to improve the ways universities and colleges fulfill their mission to serve communities. While helpful to practitioners, such evaluations of pedagogies, partnership models, assessment tools, and so on have done little to address the relationship between service-learning and the political-economic and cultural context of post-secondary education (Kliewer, 2013). At the same time, the literature connecting neo-liberalism and post-secondary education is germane to the emergence of service-learning, especially as it links transformations of the state, culture, and the academy (Canaan \& Shumar, 2008; Peters, 2011; Sears, 2003; Slaughter \& Rhoades, 2004), yet few authors on this subject discuss the service-learning movement.

In light of these gaps in the literatures on service-learning and post-secondary education, our goal in this article is to introduce a conceptual framework for exploring the relationship of service-learning to broader transformations within and beyond what many have dubbed the "neo-liberal university" (Canaan \& Shumar, 2008; Slaughter \& Rhoades, 2000). The framework we propose would support service-learning research on a series of contextual and pragmatic questions: In what ways does the ascendance of neo-liberalism underlie many Canadian universities' embrace of service-learning and other forms of community engagement? What changes have opened the way for service-learning to appear attractive and possible at a time of budgetary pressures on traditional undergraduate programs? Most importantly, what does the conjuncture of neo-liberalism and the growth of service-learning mean for instructors seeking to design critical service-learning programs and pedagogies, on the one hand, and for faculty seeking to challenge the shaping of "academic capitalism," on the other? (Slaughter \& Leslie, 1997; Slaughter \& Rhoades, 2004). 


\section{Why Service-Learning? Why Now?}

Largely an American phenomenon, service-learning emerged in Canada, Europe, Australasia, and elsewhere several years after it had been institutionalized in the United States. There the service-learning movement, in both K-12 and post-secondary education, originated in the late 1980 s and quickly became established as part of a broader approach to teaching and learning that emphasizes community or civic engagement (Stanton, Gilles, \& Cruz, 1999). Service-learning in the United States is supported by various levels of government, receives institutional and foundation funding, and has dedicated conferences and academic journals. For example, in April 2009, President Obama declared this period "the new era of service" as he signed the Edward M. Kennedy Serve America Act, allocating over a billion dollars to service-learning (Obama, 2009). In addition, a classification system offered through the Carnegie Foundation for the Advancement of Teaching deems service-learning a form of community engagement that helps confer the soughtafter status of "engaged university" (Driscoll, 2009).

Service-learning scholars have cited several antecedents to the movement in the US context but seldom place significance on the concurrence of service-learning with neo-liberalism. Zieren and Stoddard (2004), for example, trace the origins of service-learning as far back as the Morrill Act of the 1860s, which established land-grant colleges across the United States and constituted the "first national attempt to combine the liberal arts with practical and vocational learning" (p. 26). Zieren and Stoddard also tie service-learning to the community advocacy thrust of the social work curriculum during the Depression and through the civil rights era. More commonly, scholars have located the philosophical foundations of service-learning within the traditions of progressive education associated with John Dewey, the experiential learning theory of David Kolb, and critical pedagogy emerging from the adult education theory of Paolo Freire (see Brown, 2001; Deans, 1999; Rocheleau, 2004).

Similarly in Canada, some scholars also trace the roots of service-learning, more commonly known as "community service-learning," as far back as the late 19th century (Keshen, Holland, \& Moely, 2010). However, the institutionalization of service-learning in Canada gained momentum only in 2005 when the J.W. McConnell Family Foundation provided seed funding to establish or augment service-learning programs at 10 universities and funded a national association, the Canadian Alliance for Community ServiceLearning (Chambers, 2009; Smith, 2010). Service-learning in Canada has proliferated since 2005 and is now part of the academic and cocurricular calendars of many post-secondary education institutions (Chambers, 2009; Charbonneau, 2009; Fryer et al., 2007; Smith, 2010). According to one estimate in 2010, at least 50 university campuses in Canada had service-learning programs, most of which had been in existence for five years or less (Keshen et al., 2010).

While the J.W. McConnell Family Foundation funding provided a significant impetus to the growth of service-learning, the movement in Canada is an outgrowth of the new emphasis on community engagement that is receiving renewed attention in Canadian university mission statements (see for example, Axworthy, 2009; Monahan, 2010). The wider North American movement in post-secondary education for a "scholarship of engagement" (Boyer, 1990) has arisen in its turn in the context of educational restructuring, 
which itself must be understood in the context of neo-liberal policies, ideologies, and discourses of recent decades. The significance of associating service-learning with intellectual and pedagogical traditions that predate neo-liberalism is to position the service-learning movement as independent of and potentially oppositional to neo-liberal transformations of the university. However, while there may be continuity with the field of social work, social movement politics, and previous moments in the history of post-secondary education, service-learning is clearly fashioned in and by the neo-liberal turn of recent decades (Dennis, 2009; Kliewer, 2013).

\section{Neo-Liberalism as Policy, Ideology, and Governance}

In the broadest terms, the transition from Keynesian welfarism to neo-liberalism in advanced industrial states has been defined by the ascendancy of market values and characterized as radical capitalism or market fundamentalism (Giroux, 2004). However, neoliberalism is an essentially contested concept. Larner's (2000) evaluation of three ways of thinking about neo-liberalism-as policy, ideology, and governance-offers a framework, first for analyzing the context for service-learning in post-secondary education and second for interpreting contradictory evaluations of service-learning.

Understood in terms of policy, neo-liberalism is a complex process of regulatory and governance changes on a global scale through which elites have been reversing the postwar achievements of labour and social movements in the Western welfare states, rolling back workers' share of national income, reducing income security, and limiting social rights and protections (Duggan, 2003; Harvey, 2005). Since the earliest neo-liberal experiments, including those in New Zealand in the 1980s and Ontario in the mid-1990s, commentary on neo-liberalism through the lens of policy has focused on the state's retreat from direct provision of social goods (health care, education, environmental protection, public infrastructure, and so on), and its new emphasis on promoting favourable conditions for business (McBride \& Whiteside, 2011). Observers continue to remark on how governments across the political spectrum, from conservative to social democratic, have sought to extend the reach of markets through a common set of practices: privatizing public services and commodifying state assets; subverting organized labour and social movement organizations; criminalizing dissent while increasing surveillance, policing, and incarceration; and dismantling regulations on industry, banking, and finance (Coulter, 2009; Saad-Filho \& Johnston, 2005).

The role of ideology is basic to neo-liberalism-as-policy analyses. Larner (2000) describes Ideology (with a capital I) as the body of ideas that undergirds neo-liberal policy agendas. In a caricature of classical liberalism, neo-liberal Ideology asserts the primacy of individual property rights and the creed that markets serve as both the optimal mechanism for allocating goods and the guarantor of social well-being. The prefix neo- signals, in part, a new merger of economic and political liberalism, which justifies transnational corporations' and financial institutions' domination of markets by mapping individual rights onto corporate actors. Neo-liberalism also entails Ideological legitimization of steep increases in concentrations of income and wealth, as deepened social inequality is a hallmark of neo-liberal development nationally and globally (Duggan, 2003; Giroux, 2004; Harvey, 2005). 
However, following neo-Gramscian theorists such as Stuart Hall (1988) and a number of feminist thinkers, Larner presents ideology as more than a system of beliefs. Her more expansive analysis of neo-liberalism as ideology complicates notions of a consistent Ideology guiding a top-down agenda (Hall, 1988). Conceptualizing neo-liberal ideology as both "a form of rhetoric disseminated by hegemonic economic and political groups [and] the framework within which people represent their lived experience," it becomes possible to understand the capacity of neo-liberalism to absorb resistance, the widespread cultural traction of neo-liberal tenets, and the continued sway of neo-liberal programs despite evidence of their ineffectiveness (Larner, 2000, p. 12).

Examination of specific sites of neo-liberalization, such as Larner's (2000) research on New Zealand in the 1990s, reveals that "there are different configurations of neo-liberalism, and that close inspection of particular neo-liberal political projects is more likely to reveal a complex and hybrid political imaginary, rather than the straightforward implementation of a unified and coherent philosophy" (p. 12). The complexity of neo-liberalism in practice becomes visible through attention to the articulation of neo-liberal ideas with social identities, which are in turn shaped through social change and struggle, including resistance to welfare state restructuring. Neo-liberal movements and countermovements respond to each other with unpredictable outcomes, leading Larner (2000) to argue that neo-liberal rule and its resistance are deeply intertwined.

Building on these insights, Larner (2000) introduces the "short step from ideology to discourse ... from Gramsci to Foucault, and from neo-Marxism to post-structuralism" (p. 12): in other words, to a third way of thinking of neo-liberalism, as governance. As in theories of ideology, "common sense" and relations of power figure in the neo-Foucauldian governmentality literature, but power is conceptualized as diffuse and operating through agencies and authorities beyond the state or ruling class, shaping citizens' conduct and subjectivities according to market norms without reducing their formal autonomy (Dean, 2010; Ilcan \& Basok, 2004; Miller \& Rose, 2008). As Larner puts it, "While neo-liberalism may mean less government, it does not follow that there is less governance" (p. 12). Governance works "at a distance" by appealing to the desires, ideals and identities of individuals who are self-defined and socially defined as free, active, and responsible (Dean, 2010). Further, neo-liberal governance operates through discourses, institutions, and practices that construct "truth" such that citizens conduct themselves in a manner that serves the needs and interests of the state. This "truth" determines how it is possible to think and act and, conversely, what is unthinkable, impossible, inactionable, or deviant (Edwards, 2008; McHoul \& Grace, 1997). (Servage, 2009, p. 33)

Neo-liberal discourses reflect and produce specific ideals of citizenship. To be a neoliberal citizen is to valorize individualism; to self-identify as a consumer; to naturalize and accept the discipline of competitive markets and their sorting of "winners" and "losers"; to shift away from an earlier generation's conception of the citizen as a rights bearer; and to take up responsibilities for socially determined eventualities such as unemployment or ill health, which are now attributed to the bad choices of individuals. Furthermore, neo-liberal subjects are driven to emulate business entities by becoming more personally innovative, entrepreneurial, and efficient even in areas of life where markets do not operate. It is evident how such enterprising citizens serve the needs of the neo-liberal state because, as Servage (2009) explains further, "under a regime of neo-liberalism, this 
constructed 'subject,' the self-as-entrepreneur, legitimizes a declining role for government and business in social welfare (Olssen, 2006) and justifies the privatization of social needs and social problems" (p. 33).

Yet a governance perspective also maintains that neo-liberalism may be historically specific and composite. For example, Dennis (2009) declares that the present moment is dominated by "Neo-Liberalism 2.0." Neo-Liberalism 1.0 focused on market and family, and delegitimized government following the dictum famously attributed to Margaret Thatcher that "there is no such thing as society." In contrast, Neo-Liberalism 2.0 has rediscovered society and places a high value on cultivating relationships and nurturing community, conceived as a sphere of belonging, whether it be membership in civil society, in a neighbourhood, in a culture, or in a common home. Under Neo-Liberalism 2.0, according to Dennis, "a core discourse of Fraternity, which consists of an apparently apolitical notion of community and unproblematic definition of civic engagement as an a priori virtue, exists across the entirety of conventional political parties, platforms and coalitions" (pp. 156-157). Contrary to the image of neo-liberalism as diminishing the size and role of the state, Neo-Liberalism 2.0 is a project of "intensive restatification at a distance" (p. 158) whereby individuals and localities manage social risk and are tasked with social control and with delivering public services. The responsibilities of the state for public services are transferred onto individuals, while the "entrepreneurship of the self" broadens to encompass social entrepreneurship, the expectation that individuals and businesses will innovate to solve social problems (Baines, 2010; du Gay, 1996).

\section{Neo-Liberal Restructuring of Post-Secondary Education}

These perspectives of neo-liberalism as policy, ideology, and governance are reflected in the literature on the neo-liberal restructuring of post-secondary education. As Slaughter and Rhoades (2000) assert, "Public colleges and universities are exemplars of neoliberalism" (p. 73), because post-secondary institutions engage extensively with markets and the profit motive profoundly permeates their operations. From the perspective of neo-liberalism as policy, analyses of the neo-liberal university take as a starting point the chronic underfunding of the post-secondary education sector in the wake of legislated tax cuts that have reduced the state's capacity to fund social programs in general, including education (Chan \& Fisher, 2008; McMahon, 2009; Newfield, 2008; Sit, 2008). Revenue shortfall from declining government grants is driving universities and colleges to seek alternative sources of income through private-sector partnerships, competition for external grants, commercialization of the products of research and instruction, student tuition, professional and vocational degree programs, online courses, international student recruitment, and fundraising, among other strategies. Complicating this argument, Slaughter and Rhoades (2004) point out that state subsidies of universities in the United States have not, in fact, declined; institutions appear cash strapped because budget priorities have shifted toward expanding universities' administrative and research capacities to engage in entrepreneurialism. As Lewis (2008) argues, for Canada, too, university entrepreneurialism is not simply a financial exigency following from government disinvestment; rather, both developments are driven by neo-liberal ideology.

Looking beyond the question of funding reveals parallel changes that suggest that the neo-liberal turn from public purpose to market-oriented institutions is not merely a pol- 
icy response to circumstantial change, but is a broader, more ideologically driven shift. For example, one change that does not straightforwardly emanate from financial need is the way universities' governance and administrative processes increasingly mirror those of corporations (Servage, 2009; Sit, 2008). A second example is the introduction of government funding incentives for particular research and teaching activities, encouraging individuals and institutions to consider themselves in competition (Slaughter \& Leslie, 1997; Subotzky, 1999). Tied to entrepreneurial funding models are governments' increasing preference to raise tuition while funding scholarships and financial aid. Directing financial support to individual students contributes to the redefinition of access to postsecondary education as a private concern rather than a public good (Sit, 2008). Finally, universities and colleges are placing more emphasis on educating for employability and on workforce training to meet the needs of industry (Sears, 2003). Taken as a whole, the movement toward corporatization, commercialization, and privatization erodes the public character of post-secondary education in accordance with ideological tenets of neo-liberalism: education becomes a consumer good and researchers resemble "state-subsidized entrepreneurs" (Slaughter \& Leslie, 1997, p. 9; see also Chan \& Fisher, 2008).

The third perspective, neo-liberalism as governance, departs from the policy and ideology debates by problematizing how power works. The post-secondary education literature in the governmentality tradition refers to governance as a specific form of power that is not external to individuals and institutions but is bound up with everyday practices, identities, and knowledge (Dean, 2010; Miller \& Rose, 2008). Governmentality studies of education do not analyze institutional change as the result of top-down policies or ideological forces, but rather examine universities as sites of governance through the circulation of everyday knowledge (Dennis, 2009; Peters, 2011; Servage, 2009; Simons \& Masschelein, 2006).

To say that power operates through everyday practice means that subjects are not merely constrained by institutions and ideologies; instead they actively produce and circulate the discourses that help constitute institutions such as universities (Peters, 2011). More specifically, the operation of neo-liberal power is evident in the ways people become self-responsible and willing to be governed through the market. In other words, neo-liberal governance describes the process of people channelling their capacities to be entrepreneurial and self-governing so that institutional forms of control are less necessary. For example, in universities, neo-liberal governance is evident in students' desires to acquire more credentials and make themselves more marketable, or in instructors' endeavours to be pedagogically innovative.

These three critical perspectives on neo-liberalism in post-secondary education are often addressed toward different issues. For example, tuition rates are often debated through a policy lens, corporatization through the lens of ideology, and lifelong learning through the lens of governance (Servage, 2009; Simons \& Masschelein, 2006). Despite the increasing profile and claim on resources of service-learning, however, this movement has been largely absent from the critical literature on post-secondary education. At the same time, the literature on service-learning largely ignores neo-liberalism, tending to focus on learning outcomes of service-learning, whether they be technical (improving content learning and cognitive skills), cultural (fostering intercultural skills and civic engagement), political (instilling ethical and political commitment to social justice), or anti- 
foundational (encouraging critical thinking and radical questioning of received truths) (Butin, 2010). To a lesser degree, service-learning researchers also attend to outcomes for community betterment (Stoecker \& Tryon, 2009). In any case, the goal of much service-learning research is to make a case to universities, instructors, or funders about the merits of service-learning pedagogy and why it deserves support (Stanton, Gilles, \& Cruz, 1999). There is little research that links the neo-liberal context of the university to the implementation and design of service-learning. Making a similar observation in a study of students as consumers, Naidoo and Jamieson (2005) describe a bifurcation in the social sciences literature on post-secondary education: "The first tendency is for in-depth studies of student learning to be conducted in isolation from the macro context, and the second is to focus on the structural conditions and social effects of higher education while relegating academic practices to the proverbial black box" (p. 269).

In what follows, we seek to bridge this gap between analyses of context and implementation by locating the service-learning movement within the neo-liberal university and within neo-liberalism more generally, and then discussing implications for service-learning practices. As we show next, the three conceptualizations of neo-liberalism-as policy, ideology, and governance-open up different and even contradictory ways of evaluating the service-learning movement.

\section{Three Critical Perspectives on Service-Learning and Neo-Liberalism}

\section{Service-Learning as the Kind Face of the Neo-Liberal University}

One interpretation of the relationship of service-learning to the neo-liberal university follows on the conception of neo-liberalism as policy. In this view, community engagement is introduced in a top-down fashion as a type of corporate brand. Service-learning lends a positive public image to the post-secondary sector as a whole and helps institutions compete in appealing to funders and in attracting and retaining students. To put it simply, as universities increasingly reveal their corporate face, service-learning allows them to present a kinder face.

As Gumport (2000) observed, universities need to manage challenges to their legitimacy arising from restructuring in the direction of academic capitalism. Specifically, a university sector that adopts managerialism, orients teaching and research to serve industry, and focuses on revenue generation needs to worry about "loss of moral legitimacy, core purposes and values such that it is no longer recognizable and identified as the entity that it was expected to be" (Gumport, 2000, p. 85). The public sees undergraduate teaching and the liberal arts as having the broadest benefit among the functions of a university, but these areas have been the most negatively affected by the turn toward research intensiveness as their share of funding has shrunk (Slaughter \& Rhoades, 2004). Commercialization has so narrowed the scope of research as to raise doubts about the social benefit of the public subsidy to university research. Questions about the relevance of university research tie into the perception of universities as elitist and resource-rich but inaccessible to many. The ivory tower image is most problematic for prestigious urban campuses located within economically distressed communities (Chaput, 2008, p. 187).

Like corporations, universities and colleges have found they can improve their public image through conspicuous demonstrations of "giving back" to communities. Pedago- 
gies requiring student community engagement are analogous to corporate employee volunteer programs and accomplish a similar purpose (Scott, 2009). In fact, universities' public relations needs are well served by service-learning. As a kind of corporate social responsibility strategy, service-learning gives visibility to good undergraduate teaching and good works while deflecting attention away from the subsidy to narrowly focused commercialized research (Slaughter \& Rhoades, 2000).

A related way that service-learning is instrumental for universities is in increasing their rankings relative to one another. Universities are competing with one another for enrolments, and to attract and retain excellent students. Service-learning may help universities develop a positive brand and ultimately improve their appeal to students. Much has been made of the crisis of student disengagement, which refers to students' lack of interest or faith in what universities have to offer and their consequent lack of academic effort (Côté \& Allahar, 2007). In response to student disengagement, the post-secondary sector has introduced a variety of performance indicators for benchmarking progress and determining universities' rankings. These quality assurance instruments provide added impetus for service-learning, which has the potential to boost scores on measures of student engagement.

A third reason service-learning is considered good policy is its attractiveness to prospective donors, including foundations, corporations, and alumni. Since the 1970s, provincial governments' per-student funding of universities' teaching mission has fallen dramatically; in addition to raising tuition fees, universities have responded by seeking

private funding sources (Lewis, 2008). Service-learning may be appealing to funders who receive assurance of the relevance of the university to community needs. Service-learning proponents often support universities' strategic use of service-learning for elevating institutional reputations and revenues, and for fundraising (Holland, 2009, p. 91).

The benefits of community engagement to universities explain why relatively expensive service-learning programs have been implemented simultaneously with cutbacks to traditional undergraduate teaching. Charity-oriented service-learning, in particular, helps universities to appear magnanimous in the face of negative pressures arising from the neo-liberal turn. This "good-washing" of universities' public image deflects and defuses negative responses to the basic problem of underfunding of undergraduate teaching and, more generally, to the neo-liberal realignment of the purposes and priorities of postsecondary education in society.

\section{Service-Learning as a Countermovement to Neo-Liberalism}

Service-learning instructors are unlikely to regard themselves as carrying out a neoliberal policy agenda as described above. On the contrary, instructors commonly understand neo-liberalism as a system of ideas that may be contested and resisted. This framing allows them to understand service-learning as counteracting neo-liberal ideology by, for example, supporting students to think beyond consumer identities, or by teaching democratic citizenship in ways that foreground and positively value the political (Frazer, 2007; Milofsky \& Flack, 2005). Practitioners also situate service-learning within the longstanding traditions of social critique that are safeguarded by universities' codes of academic freedom. 
Practitioners would tend to regard the comparison of service-learning to corporate social responsibility programs as resting on a thin understanding of service-learning as merely the performance of community service for academic credit. In contrast, following Clayton and Ash (2004) and Howard (1998), service-learning proponents identify it as a "counternormative" pedagogy. Fundamentally, this means that service-learning departs from the traditional information-dissemination model of learning, in which instructors control the learning environment. The core work of the service-learning instructor is to structure and facilitate an integration of academic and experiential learning by engaging students in practices of reflection. Depending on how course designers conceive of "service" in this model and how they incorporate critical reflection, pedagogies of service-learning can go from being counternormative to counterhegemonic. Much service-learning programming is apolitical: that is, oriented more toward charitable activity or helpful projects than toward social change (Feigenbaum, 2008; Hollander \& Hartley, 2009; Morton, 1995). But a sizable literature delineates how service-learning can be a critical or social justice pedagogy (Brown, 2001; Butin, 2008; Camacho, 2004; Kajner, Chovanee, Underwood, \& Mian, 2013; King, 2004; Koliba, 2004; Mitchell, 2008; Swords \& Keily, 2010).

In thinking of service-learning as a social justice pedagogy, however, some practitioners position it outside of neo-liberalism. For example, speaking from the perspective of community colleges, Ayers (2005) interprets the proliferation of service-learning programs as evidence that "even though the neoliberal ideological norms of late modernity have permeated the discourse of community college education, this permeation is neither absolute nor universal" (p. 547). As Levidow (2002) similarly explains, "Universities represent the needs of the state and capital as the needs of society. . . Despite this role, often spaces are created for alternative pedagogies and critical citizenship" (p. 227), as exemplified by service-learning. Universities continue to provide a space for social critique, including critique of market society, which can be a resource for student-led, campus-based activism such as movements for wider access to education, for fair trade, and against sweatshops. Service-learning proponents tend to regard their pedagogical work as similarly activist with respect to countering the neo-liberalization of the academy. For example, Shumar (2008) describes his department's embrace of service-learning as the "antidote to the shopping mall education and the culture of consumption that is coming to dominate the university" (p. 80). Subotzky (1999), likewise, holds that "the communityservice partnership model represents a significant counter-trend to the entrepreneurial university" (p. 436).

Unfortunately, this image of service-learning as oppositional to neo-liberal ideology overestimates the coherence of both service-learning and neo-liberalism, and may oversimplify what happens in service-learning courses. Instructors who make social justice central to their work need to acknowledge their lack of control in service-learning. Though they may design courses that highlight the need for social action to challenge structural violence, inequality, oppression, or privilege, "the service-learning movement has oftentimes downplayed or glossed over the minimal social justice outcomes of service-learning practices" (Butin, 2010, p. 41).

Not only is it too much to expect that service-learning can accomplish significant social betterment, it is also the case that many community partners and students miss or resist the social justice framing of service-learning. For example, Swaminanthan (2008) 
interviewed supervisors of service-learning students at community partner agencies to discover a "hidden curriculum" of service-learning at their sites. The interviews revealed that community supervisors were "playing significant mentoring and teaching roles" with students and were "interested in helping students acquire specific skills and traits" linked to labour market preparation and reinforcing dominant stereotypes (pp. 40, 41). Because instructors were unaware of the community supervisors' goals, "the hidden curricula resulted in mitigating the social justice education focus of teachers at the partnering school" (p. 34). Parallel accounts exist of students who do not embrace learning outcomes linked to social justice learning, given their preference for charity over advocacy, for example (see Moely, Furco, \& Reed, 2008).

The failure of some service-learning proponents to oppose neo-liberalism as policy (by supporting its public relations role) and of others to counteract neo-liberalism as ideology (by underestimating how neo-liberal values may be disseminated within the sites of service-learning) suggests not so much the problematic nature of service-learning as the limitations of these framings of neo-liberalism. To return to Larner's (2000) argument, both the policy and Ideology perspectives posit neo-liberalism as monolithic and as external to its opponents. In her observation, "Many of those who would contest this policy agenda unwittingly reinforce the coherence of neo-liberalism" (p. 15). In other words, because many critics of monolithic neo-liberalism take it to be imposed from above, rather than blended into routine practice, they "inadvertently reconstruct its hegemony" (p. 15). A governance perspective on neo-liberalism, in contrast, would help us to evaluate the oppositional potential of service-learning differently by allowing us, in Larner's words, to "[recognize] that political 'resistance' is figured by and within, rather than being external to, the regimes of power" (p. 17).

\section{Service-Learning as a Site of Neo-Liberal Governance}

The perspectives we have presented above position service-learning on either side of a binary: as a neo-liberal strategy or as a counterstrategy, an "alternative" pedagogy (Levidow, 2002). A third possibility, which would move us beyond this oppositional framework, would be to examine service-learning in Foucauldian terms as a site of neo-liberal governance. This perspective would examine how service-learning reflects and produces neo-liberal discourses, such as individual responsibility and social entrepreneurialism. For Dennis (2009), service-learning is the practice of cultivating "responsibilized service providers and moral subjects" (p. 170), which defines the latest iteration of the neo-liberal project:

Apart from their traditional functions, [universities and colleges] are occupied, as matters of morality, economics, political ambition and institutional survival, with the wholesale orientation of a generation of college students, and the reorientation of staff and academics, away from both a Keynesian state-centrered welfarist model and the subsequent econometric Neoliberal 1.o model to the responsibilization practices ... inherent in the sociocentrism of Neo-Liberalism 2.o. (Dennis, 2009, p. 166)

Neo-liberal governance works through service-learning primarily in two ways. First, as Dennis (2009) explains, through service-learning students develop civic identities that are aligned with the priorities of the state. The state's underfunding and residualization of 
social services intensifies the need for charity and volunteering. Work that had once been the responsibility of the state is transferred onto civic organizations and their responsibilized members, who are "restatified at a distance" (Dennis, 2009, p. 158). Universities facilitate the privatization and outsourcing of civic work to volunteers by producing socially engaged citizens with an orientation and willingness to bear the costs of caring for community. The service-learning movement is at the forefront of this cultural project of fostering and valorizing citizen-volunteer identities.

Second, in addition to cultivating students (and their institutions) to be caring and socially responsible, service-learning makes the disposition to volunteer into a credential, which students are encouraged to display on their transcripts and resumés and in electronic portfolios (Cambridge, 2010; Jacoby, 1999). Not only are service-learning courses considered more relevant to "real world" issues, but the practice of incorporating servicelearning experience into personal identity statements makes students more marketable. Service-learning gives students a competitive advantage by helping them develop and perform self-reflection and personal morality, as well as by stimulating entrepreneurial desires to remake both the self and the social.

Governmentality theory emphasizes that pleasures and rewards are as important to governance as are fear and coercion (Miller \& Rose, 2008). The pleasures and rewards of performing "social responsibility" in a neo-liberal context account for the attractiveness of service-learning to a range of people who promote the pedagogy, including senior administrators, staff, faculty, students, and community partners. Whereas a neo-liberalism-as-ideology analysis would underscore these constituents' divergent perspectives on the mission of the university, a neo-liberalism-as-governance perspective shows how service-learning masks and contains conflicting interests at work in the university's mission of service (Chaput, 2008). The governance perspective also reveals how particular neo-liberal dispositions toward social responsibility and social entrepreneurship eclipse other identities and aspirations, such as social movement activism and education for its own sake (Servage, 2009).

\section{Conclusion: Critical Service-Learning?}

Our goal in this article has been to explore how service-learning is embedded in the neo-liberal university, whether that relationship be instrumental, oppositional, or a mode of self-governing through moral agency. We have approached the task by showing how different theoretical understandings of neo-liberalism map onto contrasting assessments of service-learning: as a vehicle for public relations, an approach to counteracting commercialization and corporatization, or an ensemble of individualizing, responsibilizing discourses. Though apparently contradictory, these analyses are not completely antithetical. Any given service-learning program could perform contradictory roles within an institution: a program could be co-opted as a form of community-university outreach, while at the same time introducing students to perspectives that challenge the market creed and simultaneously equipping them to be socially enterprising, self-commodifying neo-liberal citizens. Nor do these arguments apply to service-learning across the board: some servicelearning courses may be more easily co-opted into institutional marketing campaigns than others; some may represent a stronger critique of market fundamentalism than others; and some may be more vocationally oriented, individualizing, or responsibilizing than others. 
Our purpose is not to propose one critique of service-learning as more valid than the others. Nor do we seek to reconcile contradictions among perspectives on neo-liberalism as policy, ideology, or governance. Following Springer (2012), we maintain "there is no 'pure' or 'paradigmatic' version of neoliberalism" (p. 136). Like Larner (2000), Springer identifies distinct ways scholars understand the construct, but he argues that, while these theoretical positions "are not entirely commensurable, their content is not diametrically opposed" (p. 143). In particular, he holds that Marxist-inspired and post-structural conceptions of neo-liberalism are not as incompatible as commonly held. In this spirit, we too suggest that critical evaluations of the relationship of service-learning to neo-liberalism derived from different conceptualizations of neo-liberalism are not mutually exclusive. Given the variations and contradictions within neo-liberalism, Larner's (2000) framework for examining it as policy, ideology, or governance may help future researchers address the ongoing layers of congruence and contestation between neo-liberalism and service-learning-and the way they shape each other.

By way of conclusion, we offer an example of how such a complex analysis of neoliberalism has informed our design of one critical service-learning course. In teaching the high-enrolment social sciences elective Foundations for Community Engagement, we have attempted to follow Butin's (2006) recommendation: "Rather than continuing to think about service-learning as a politics to transform higher education and society, we might more fruitfully reverse the terminology and begin to think through service-learning about the politics of transforming higher education and society" (p. 492). Because servicelearning emphasizes self-reflection and students' situated struggles as the ground of their learning, service-learning has the potential to introduce a critique of neo-liberal policy, ideology, and governance within and beyond the university. The critical approaches employed in the Foundations course flow from each of the perspectives we have introduced.

Before explaining further, a brief overview of the organization of the course is required. Foundations for Community Engagement, which is open to any student without prerequisite, involves a series of self-guided field trips, or "out-of-classroom learning opportunities" (OOCLOs), which students select from a list of dozens of suggested activities. For example, students may attend a public lecture, a documentary film screening, or the annual general meeting of a non-profit organization. They may visit a historic site or an art gallery, march in a public demonstration for a cause they support, attend a meeting of local government, help newcomers practise English at a drop-in conversation circle, contribute physical labour for a community garden, attend a farmers' market, and so on. OOCLOs relate to a broad range of topics such as local arts, history and heritage, agriculture and food, religion, architecture, ecology and environmental movements, schooling, transportation, public health, housing, local government, animal rights, women's and labour issues, literacy, indigenous movements and culture, local industries, the built environment, local media, and so on. In essence, students engage in community ethnography with a focus on public participation, local knowledge, and local social issues. They select one OOCLO every second week over 24 weeks and submit a structured reflection about it before attending a biweekly lecture and a small-group tutorial where they discuss readings and theoretical perspectives on the broad course themes.

In contrast to many service-learning courses, students do not complete a project or fulfill a quota of service hours for a particular organization. At our university, student interac- 
tion with wider communities is limited by the university's self-contained campus, which is accessible by highway and located at a distance from downtown. Therefore, students' public participation constitutes "service" in that it fills a community need for invigorated public space in an economically depressed city hollowed out by suburbanization and the loss of industrial manufacturing. Students may also participate in OOCLOs at the university, where they serve by contributing to student life on a largely commuter campus.

How does such a course address the three critiques of service-learning as neo-liberal? Concerned with the framing of service-learning as neo-liberal policy, Scott (2009) asks rhetorically, "To what extent should our service-learning programs and pedagogies support, and position our students to support, the public relations and marketing practices of corporations (including universities) that have all-too-astutely adapted the rhetoric of civic engagement?" Certainly, the Foundations course has had positive publicity, which we have welcomed, recognizing that the university is bound to capitalize on good outcomes. However, the course is not a mere screen that deflects criticism of the university. For example, among the OOCLO options are opportunities to participate in student-driven campaigns related to affordable education, campus sustainability, ethical purchasing policies, prevention of bullying, harassment, rape and sexual assault on campus, and so on. Such activities foster critiques of university policies, which is a step toward constituting the university, including its service-learning initiatives, as a political arena.

Second, the Foundations course counters neo-liberal ideology insofar as critical analysis of core concepts within service-learning is central to the taught component of the course. Students come to understand service, citizenship, and community as contested terms. The exposure to many forms of community involvement challenges service-learning's common emphasis on charitable volunteering. Through social activism, civic participation, and fostering democratic public spaces, students recognize multiple ways to "serve." In this way, the course illustrates a number of the strategies Koliba (2004) proposes as ways to "learn our way out" of privatized citizenship. In particular, we have focused on "creating a safe space for 'political talk' within the classroom," "problematizing the notion of service itself," and "conveying the relationship between service-learning and wider institutional reform” (p. 62).

Addressing the third perspective, however, we recognize that even critical service-learning initiatives may work as technologies of neo-liberal governance. For example, though students may critically identify aspects of their service-learning, such as volunteering and credential seeking, as serving the neo-liberal state, they nevertheless may embrace such practices not only for their own economic survival but also for the pleasures of becoming self-realized neo-liberal subjects through such activities (Miller \& Rose, 2008), just as instructors may take up service-learning partly as a project of the self, to become enterprising, socially responsible and pedagogically innovative (Simons \& Masschelein, 2006).

The conception of service-learning as neo-liberal governance, therefore, presents a challenge for critical pedagogies. In the Foundations course, we attempted to meet this challenge through an emphasis on critical reflection. We offered students prompting questions for reflection on their first and subsequent drafts with the aim that reflections could be a vehicle to self-interrogate neo-liberal subjectivities. For the most part the written reflections seemed to reproduce neo-liberal discourses of self-responsibility and individualized charity, but often they surfaced ambivalence and tensions toward and within 
these discourses. At their most successful, reflections helped students recognize that neoliberal power works by regulating their desires to be market-oriented and entrepreneurial in the way they approach personal needs and social issues (Dean, 2010). The potential of reflection in service-learning, then, is to reveal identifications with market mentalities as complex and problematic, but also as mutable. Critical reflection can open the way for imagining alternatives to neo-liberal policies, rethinking neo-liberal ideologies, and, just as crucially, examining the self in order to reshape neo-liberal governance in the direction of social justice.

In this article, we have offered a way to understand contradictory evaluations of service-learning by linking them to different conceptualizations of neo-liberalism. For example, service-learning in Canada, including the Foundations course at our university, has been introduced during a time of austerity, privatization, and commercialization within post-secondary education, yet the enthusiasm for service-learning among critical scholar-practitioners such as ourselves has been matched by the interest in this pedagogy by university administrators. Further analysis is needed of the relationship of emerging varieties of neo-liberalism and service-learning, especially research leading to pedagogical strategies that help students and instructors engage more intentionally and creatively with the neo-liberal politics of service-learning and post-secondary education.

\section{References}

Axworthy, L. (2009). The university and community learning: An evolving mission. Winnipeg, MB: University of Winnipeg. Retrieved from http://uwinnipeg.ca/index/cmsfilesystem-action/pdfs/admin/uwinnipeg-and-community-learning.pdf

Ayers, D. F. (2005). Neoliberal ideology in community college mission statements: A critical discourse analysis. The Review of Higher Education, 28(4), 527-549.

Baines, D. (2010). Neoliberal restructuring, activism/participation, and social unionism in the nonprofit social services. Nonprofit and Voluntary Quarterly, 39(1), $10-28$.

Boyer, E. L. (1990). Scholarship reconsidered: Practices of the professoriate. Stanford, CA: Carnegie Foundation for the Advancement of Teaching.

Bringle, R. G., \& Clayton, P. H. (2012). Civic education through service learning: What, how, and why? In L. McIlraith, A. Lyons, \& R. Munck (Eds.), Higher education and civic engagement: Comparative perspectives (pp. 101-124). New York, NY: Palgrave Macmillan.

Brown, D. M. (2001). Pulling it together: A method for developing service-learning and community partnerships based in critical pedagogy. Washington, DC: Corporation for National Service.

Butin, D. W. (2006). The limits of service-learning in higher education. The Review of Higher Education, 29(4), 473-498.

Butin, D. W. (Ed.). (2008). Service-learning and social justice education: Strengthening justice-oriented community based models of teaching and learning. New York, NY: Routledge. 
Butin, D. W. (2010). Service-learning in theory and practice. New York, NY: Palgrave Macmillan.

Camacho, M. M. (2004). Power and privilege: community service learning in Tijuana. Michigan Journal of Community Service Learning, 2(10), 31-42.

Cambridge, D. (2010). Eportfolios for lifelong learning and assessment. San Francisco, CA: Jossey-Bass.

Canaan, J. E., \& Shumar, W. (Eds.). (2008). Structure and agency in the neoliberal university. New York, NY: Routledge.

Chambers, T. (2009). A continuum of approaches to service-learning within Canadian post-secondary education. Canadian Journal of Higher Education, 39(2), 77-100.

Chan, A. S., \& Fisher, D. (Eds.). (2008). The exchange university: Corporatization of academic culture. Vancouver, BC: UBC Press.

Chaput, C. (2008). Inside the teaching machine: Rhetoric and the globalization of the U.S. public research university. Tuscaloosa, AL: University of Alabama Press.

Charbonneau, L. (2009). Community connections. University Affairs/Affaires Universitaires. Retrieved from http://www.universityaffairs.ca/features/feature-article/ community-connections/

Clayton, P. H., \& Ash, S. L. (2004). Shifts in perspective: Capitalizing on the counternormative nature of service-learning. Michigan Journal of Community Service Learning, 11(1), 59-70.

Côté, J. E., \& Allahar, A. L. (2007). Ivory tower blues: A university system in crisis. Toronto, ON: University of Toronto Press.

Coulter, K. (2009). Deep neoliberal integration: The production of third way politics in Ontario. Studies in Political Economy, 83, 191-208.

Dean, M. (2010). Governmentality: Power and rule in modern society (2nd ed.). Thousand Oaks, CA: Sage Publications.

Deans, T. (1999). Service-learning in two keys: Paulo Freire's critical pedagogy in relation to John Dewey's pragmatism. Michigan Journal of Community Service Learning, 6(1), 15-29.

Dennis, D. (2009). The shepherd, the marketer and the actuary: Education-based service learning and civic engagement as neo-liberal governmentalities. In S. Binkley \& J. Capetillo (Eds.), A Foucault for the 21st century: Governmentality, biopolitics and discipline in the new millennium (pp. 154-172). Newcastle upon Tyne, UK: Cambridge Scholars Publishing.

Driscoll, A. (2009). Carnegie's new community engagement classifications: Affirming higher education's role in community. New Directions for Higher Education, 147, 5-12.

du Gay, P. (1996). Consumption and Identity at Work. London, UK: Sage Publications.

Duggan, L. (2003). The twilight of equality? Neoliberalism, cultural politics and the attack on democracy. Boston, MA: Beacon Press. 
Feigenbaum, P. T. (2008). Community action: A framework for egalitarian, reciprocal community engagement in the field of rhetoric and composition (Doctoral dissertation). Retrieved from http://deepblue.lib.umich.edu/handle/2027.42/60844

Frazer, E. (2007). Depoliticizing citizenship. British Journal of Educational Studies, 55(3), 249-263.

Fryer, M., Wallis, R., Sattar, K., Annette, J., Battistoni, R., \& Lund-Chaix, A. (2007). Context and culture: Models of engagement around the world. In S. B. Gelmon \& S. H. Billig (Eds.), From passion to objectivity: International and cross-disciplinary perspectives on service learning research (pp. 3-20). Greenwich, CT: Information Age Publishing.

Giroux, H. A. (2004). The terror of neoliberalism: Authoritarianism and the eclipse of democracy. Boulder, CO: Paradigm.

Gumport, P. J. (2000). Academic restructuring: Organizational change and institutional imperatives. Higher Education, 39(1), 67-91.

Hall, S. (1988). The toad in the garden: Thatcherism among the theorists. In C. Nelson \& L. Grossberg (Eds.), Marxism and the interpretation of culture (pp. 35-57). London, UK: Macmillan Education.

Harvey, D. (2005). A brief history of neoliberalism. Oxford, UK: Oxford University Press.

Holland, B. A. (2009). Will it last? Evidence of institutionalization at Carnegie classified community engagement institutions. New Directions for Higher Education, 147, 85-98.

Hollander, E., \& Hartley, M. (2009). Introductory essay: Reimagining the civic imperative of higher education. In D. W. M. Barker \& D. W. Brown (Eds.), A different kind of politics: Readings on the role of higher education in democracy (pp. 1-14). Dayton, $\mathrm{OH}$ : Kettering Foundation Press.

Howard, J. P. F. (1998). Academic service learning: A counternormative pedagogy. New Directions for Teaching and Learning, 1998(73), 21-29.

Ilcan, S., \& Basok, T. (2004). Community government: voluntary agencies, social justice, and the responsibilization of citizens. Citizenship Studies, 8(2), 129-144.

Jackson, E. (2014). Community-university engagement in Canada: Voices from the field. Retrieved from http://communityresearchcanada.ca/res/download.php?id=5124

Jacoby, B. (1999). Partnerships for service learning. New Directions for Higher Education, 87, 19-35.

Kajner, T., Chovanee, D., Underwood, M., \& Mian, A. (2013). Critical community service-learning: Combining critical classroom pedagogy with activist community placements. Michigan Journal of Community Service Learning, 19(2), 36-48.

Keshen, J., Holland, B. A., \& Moely, B. E. (2010). Introduction. In J. Keshen, B. A. Holland, \& B. E. Moely (Eds.), Research for what? Making engaged scholarship matter (pp. ix-xviii). Charlotte, NC: Information Age Publishing.

King, J.T. (2004). Service-learning as a site for critical pedagogy: Acase of collaboration, caring, and defamiliarization across borders. Journal of Experiential Education, 26(3), 121-137. 
Kliewer, B. W. (2013). Why the civic engagement movement cannot achieve democratic and justice aims. Michigan Journal of Community Service Learning, 19(2), 72-79.

Koliba, C. J. (2004). Service-learning and the downsizing of democracy: Learning our way out. Michigan Journal of Community Service Learning, 1O(2), 57-68.

Larner, W. (2000). Neo-liberalism: Policy, ideology, governmentality. Studies in Political Economy, 63, 5-25.

Levidow, L. (2002). Marketizing higher education: Neoliberal strategies and counterstrategies. In K. Robins \& F. Webster (Eds.), The virtual university? Knowledge, markets and management (pp. 227-248). Oxford, UK: Oxford University Press.

Lewis, M. (2008). Public good or private value: A critique of the commodification of knowledge in higher education-A Canadian perspective. In J. E. Canaan \& W. Shumar (Eds.), Structure and agency in the neoliberal university (pp. 45-66). New York, NY: Routledge.

Lightstone, J. (2014, January 7). Instead of Ivory Tower, a place in the neighbourhood. The Globe and Mail. Retrieved from http://www.theglobeandmail.com/news/national/ education/instead-of-ivory-tower-a-place-in-the-neighbourhood/article16169887/

McBride, S., \& Whiteside, H. (2011). Private affluence, public austerity: Economic crisis and democratic malaise in Canada. Halifax, NS: Fernwood Publishing.

McMahon, W. W. (2009). Higher learning, greater good: The private and social benefits of higher education. Baltimore, MD: John Hopkins University Press.

Miller, P., \& Rose, N. (2008). Governing the present. Cambridge, UK: Polity Press.

Milofsky, C., \& Flack, W. F. (2005). Service-learning as a source of identity change in Bucknell, Northern Ireland. In D. W. Butin (Ed.), Service-learning in higher education: Critical issues and directions (pp. 157-171). New York, NY: Palgrave Macmillan.

Mitchell, T. D. (2008). Traditional vs. critical service-learning: Engaging the literature to differentiate two models. Michigan Journal of Community Service Learning, 14(2), $50-65$.

Moely, B. E., Furco, A., \& Reed, J. (2008). Charity and social change: The impact of individual preferences on service-learning outcomes. Michigan Journal of Community Service Learning, 15(1), 37-48.

Monahan, P. (2010). Building a more engaged university: Strategic directions for York University 2010-202O. Toronto, ON: York University. Retrieved from http://vpap. info.yorku.ca/files/2012/o9/White_Paper_Overview_April_15.pdf

Morton, K. (1995). The irony of service: Charity, project and social change in servicelearning. Michigan Journal of Community Service Learning, 2(1), 19-32.

Naidoo, R., \& Jamieson, I. (2005). Empowering participants or corroding learning? Towards a research agenda on the impact of student consumerism in higher education. Journal of Education Policy, 20(3), 267-281.

Newfield, C. (2008). Unmaking the public university: The forty-year assault on the middle class. Cambridge, MA: Harvard University Press. 
Obama, B. (2009). Remarks by the President at Signing of the Edward M. Kennedy Serve America Act. Washington, DC: The White House, Office of the Press Secretary. Retrieved from http://www.whitehouse.gov/the_press_office/Remarks-by-the-Presidentat-Signing-of-the-Edward-M-Kennedy-Serve-America-Act

Peters, M. A. (2011). Neoliberalism and after? Education, social policy, and the crisis of western capitalism. New York, NY: Peter Lang.

Rocheleau, J. (2004). Theoretical roots of service-learning: Progressive education and the development of citizenship. In B. W. Speck \& S. L. Hoppe (Eds.), Service-learning: History, theory, and issues (pp. 3-21). Westport, CT: Praeger.

Saad-Filho, A., \& Johnston, D. (2005). Neoliberalism: A critical reader. London, UK: Pluto Press.

Scott, B. J. (2009). Civic engagement as risk management and public relations: What the pharmaceutical industry can teach us about service-learning. College Composition and Communication, 61(2), 343-367.

Sears, A. (2003). Retooling the mind factory: Education in a lean state. Aurora, ON: Garamond Press.

Servage, L. (2009). The scholarship of teaching and learning and the neo-liberalization of higher education: Constructing the 'entrepreneurial learner.' Canadian Journal of Higher Education, 39(2), 25-44.

Shumar, W. (2008). Space, place and the American university. In J. E. Canaan \& W. Shumar (Eds.), Structure and agency in the neoliberal university (pp. 67-83). New York, NY: Routledge.

Simons, M., \& Masschelein, J. (2006). The learning society and governmentality: An introduction. Educational Philosophy and Theory, 38(4), 417-430.

Sit, V. (2008). The erosion of the university as a public sphere. Education Canada, 48(4), 30-33.

Slaughter, S., \& Leslie, L. L. (1997). Academic capitalism: Politics, policies, and the entrepreneurial university. Baltimore, MD: Johns Hopkins University Press.

Slaughter, S., \& Rhoades, G. (2000). The neo-liberal university. New Labor Forum, 6(Spring/Summer), 73-79.

Slaughter, S., \& Rhoades, G. (2004). Academic Capitalism and the New Economy: Markets, State, and Higher Education. Baltimore, MD: Johns Hopkins University Press.

Smith, T. S. (2010). Rhetorical strategies of the postsecondary community servicelearning movement in Canada. Partnerships: A Journal of Service-Learning and Community Engagement, 1(2), 1-18.

Springer, S. (2012). Neoliberalism as discourse: Between Foucauldian political economy and Marxian poststructuralism. Critical Discourse Studies, 9(2), 133-147.

Stanton, T., Gilles, D., \& Cruz, N. I. (1999). Service-learning: A movement's founders reflect on its origins, practice and future. San Francisco, CA: Jossey Bass.

Stoecker, R., \& Tryon, E. A. (Eds.). (2009). The unheard voices: Community organizations and service learning. Philadelphia, PA: Temple University Press. 
Subotzky, G. (1999). Alternatives to the entrepreneurial university: New modes of knowledge production in community service programs. Higher Education, 38(4), 401440.

Swaminanthan, R. (2008). Educating for the 'real world': The hidden curriculum of community service-learning. In D. W. Butin (Ed.), Service-learning and social justice education: Strengthening justice-oriented community based models of teaching and learning. New York, NY: Routledge.

Swords, A. C. S., \& Keily, R. (2010). Beyond pedagogy: Service learning as movement building in higher education. Journal of Community Practice, 18(2-3), 148-170.

Zieren, G. R., \& Stoddard, P. H. (2004). The historical origins of service-learning in the nineteenth and twentieth centuries: The transplanted and indigenous traditions. In B. W. Speck \& S. L. Hoppe (Eds.), Service-learning: History, theory, and issues (pp. 23-42). Westport, CT: Praeger.

\section{Contact Information}

Mary-Beth Raddon

Department of Sociology

Brock University

mraddon@brocku.ca

Mary-Beth Raddon is associate professor of sociology and served as the faculty associate for service-learning with the Centre for Pedagogical Innovation at Brock University, St. Catharines, Ont.

Barbara Harrison is a research associate at the Community Engaged Scholarship Institute/Research Shop. at the University of Guelph. She completed her PhD in the Faculty of Education at Brock University, where she was involved in an institution-wide servicelearning initiative.

The authors designed and twice co-taught a high-enrolment service-learning elective at Brock University. 